\title{
Sustainable Competitive Advantage through Corporate Social Responsibility (CSR) and Green Behavior Strategies
}

\author{
Ahmed Abubakar $\mathbb{D}^{1},{ }^{1}$ Shweta Belwal, ${ }^{1}$ Nuhu Mohammed, ${ }^{2}$ \\ and Umaru Danladi Mohammed ${ }^{3}$ \\ ${ }^{1}$ Faculty of Business, Sohar University, Sohar, Oman \\ ${ }^{2}$ Department of Business Management, Baze University, Abuja, Nigeria \\ ${ }^{3}$ Department of Business Administration, University of Abuja, Abuja, Nigeria \\ Correspondence should be addressed to Ahmed Abubakar; ahmedaphd@gmail.com
}

Received 18 December 2021; Revised 16 February 2022; Accepted 17 February 2022; Published 7 March 2022

Academic Editor: Marcio Eisencraft

Copyright (c) 2022 Ahmed Abubakar et al. This is an open access article distributed under the Creative Commons Attribution License, which permits unrestricted use, distribution, and reproduction in any medium, provided the original work is properly cited.

\begin{abstract}
Driven by the pursuit of sustainable competitive advantage and consideration of the impact of corporate social responsibility activities on society and the need for environmentally friendly behaviors to improve companies' sustainable performance, this study investigates the impact of corporate social responsibility (CSR) on firm performance through the use of green behavior. An empirical survey was carried out, data was collected from 176 respondents, constituting a $61.8 \%$ response rate of the sample of 278 employees, and the hypotheses derived from the literature review were tested using structural equation modeling. Firm performance was empirically found to be significantly impacted by both CSR and green behavior. Furthermore, the findings suggest that green behavior mediates the relationships between CSR and firm performance. By establishing the mediating role of green behavior, the study contributes to and expands the literature on firm performance and sustainable competitive advantage. Companies, thereby adopting green behavior, can enhance a firm's performance and attain a sustainable competitive advantage.
\end{abstract}

\section{Introduction}

Increased business competition compels companies to provide consumers with appealing values, uniqueness, and novelty. Environmental management is one such aspect where the business tries to improve its reputation and overall performance. Environmental sustainability, as such, has become an area of research [1]. Globalization and greening are widely discussed topics in society, encouraging businesses to contribute to the environment and provide enhanced value to their consumers [2-5]. The contemporary business environment is hostile and full of uncertainties [6]. As a concept, corporate social responsibility (CSR) encourages businesses to think about the environment in which they work in order to improve their reputation and gain the reciprocity of their stakeholders.

Similarly, to cope with global warming and environmental change, businesses, as economic actors, should bear responsibility for environmental protection [7]. They must engage in environmental control practices and become more sustainable by reducing their environmental impact, leading to sustainable positive outcomes in their business procedures. The question remains as to how easily companies can sustain their CSR strategy for long-term competitive advantage. There have been studies conducted in the area of environmentally-based business practices, ranging from the employee level to the strategy level, some in the area of human resources [8, 9], covering green behavior $[1,5,10,11]$, and employee well-being [12]. Employees in any company are the implementers and users of policies and strategies and, as such, play an important role in shaping environmentally friendly business activities. Therefore, there is a great need for green behavior in the workplace.

Furthermore, according to empirical studies, "green behavior" as an individual behavior contributes to environmental sustainability $[11,13]$. It also encourages 
businesses to develop green innovation [14-16]. Environmentally conscious employees add value to the company's image [14] as they work as face-to-face employees, engaging directly with the customers. When a company provides a work environment valuing environmental concerns, the company's innovations always elevate environmental values $[14,16]$. Previous research has clearly examined the activities of environmentally-based companies at the corporate level as they relate to CSR and firm performance. However, the literature has yet to provide evidence of the combined impact of CSR and green behavior on company long-term performance. As a result, this study attempts to bridge this gap by establishing the role of green behavior as a mediator between CSR and firm performance. Section 2 talks about the theoretical background that led to the creation of the research question.

\section{Theoretical Background and Hypotheses}

2.1. Corporate Social Responsibility (CSR). Corporate Social Responsibility (CSR) is ultimately a strategic issue that cannot be segregated from the overall strategy of the company [17]. It can be defined as providing services to people, communities, and the environment that go above and beyond what is required by law [18]. It can also be linked to sustainability performance and competitive advantage [19]. Furthermore, Vishwanathan et al. [20] defined CSR as a firm's activity that can improve the firm financially by elevating its reputation, increasing stakeholder reciprocation, mitigating firm-specific risk, and/or improving innovation [20]. CSR can help a company's position by providing differentiation and/or cost advantages. A company's reputation and brand value can also be used to supplement a differentiation strategy. If the benefits created by CSR investments withstand competition, a CSR strategy may create long-term competitive advantages that can generate extraordinary future profits [21]. In a nutshell, CSR refers to strategies that companies implement as part of corporate governance to ensure that their operations are ethical and beneficial to society. Section 2.2 gives an overview of the relevant CSR literature as it relates to the performance of a company.

\subsection{Corporate Social Responsibility (CSR) and Firm} Performance. According to McWilliams and Siegel [22]; from a resource-based perspective, a CSR strategy together with a differentiation strategy can improve a firm's reputation and its brand value, as such a CSR strategy as a cospecialized asset can increase the value of other assets. Firms' investment in CSR acts as an important factor in providing a firm with a sustainable competitive advantage as it enhances the reputation of the corporation. Therefore, investments in firm reputation work as self-reinforcing processes, resulting in enhancement of the firm's reputation and performance [23]. CSR can have a positive impact on firm performance by increasing employee and customer satisfaction. Firms with better CSR face fewer employee problems as customers view their products more favorably [24]. Serves and Tamayo [25] suggest that CSR is positively related to firm value with high customer awareness [25]. It may also result in improved relationships with stakeholders such as bankers, investors, and the government, benefiting the firm. Firms with higher CSR ratings have easier access to finance [26]. Furthermore, stakeholder theory contends that firm value is influenced by implicit claims [27] and that if a company fails to act responsibly, parties to implicit contracts may attempt to convert them into explicit contracts, raising the company's costs [24].

Porter and Kramer [28] argue that CSR will become increasingly important for firm success, and the majority of their growth in earnings will come by creating shared economic and social value. Firms, therefore, can integrate mainstream and sustainability strategies by working through tensions in specific tasks between product features, values, and goals, allowing the sustainability strategy to be legitimized while both strategies are implemented [29]. Porter and Kramer [30] contend that shared value can be created by reimagining products and services along the value chain by reducing costs and through cluster development. Similarly, Khan et al. [31] discover that firms that invest in material sustainability issues have significantly higher profit margins, stock returns, and sales growth. Corporate Social Responsibility (CSR) directly impacts green behavior in employees [1], which positively affects the firm's performance. Therefore, the following hypothesis was developed for empirical validation:

Hypothesis 1. CSR has a significant positive effect on firm performance

2.3. Green Behavior. Recent environmental disasters have occurred as a result of human and organizational activities like excessive tree cutting, use of fossil fuels, and the release of carbon monoxide [32]. People are currently facing serious challenges due to overexploitation of human resources, environmental degradation, and unsustainable living standards [33]. Several European Union (EU) policy initiatives, such as the 2008 EU Sustainable Consumption, Production, and Sustainable Industrial Policy Action Plans, encourage green behavior. Green behavior is proenvironmental and, to the greatest extent possible, minimizes or even benefits the environment [34]. It has to do with reducing energy consumption and waste.

“Green behavior” includes employees' actions to perform work in an environmentally friendly manner (De Roeck and Farooq [35]; where recycling, resource conservation, participation in environmental initiatives, and the implementation of more environmentally friendly policies are just a few examples. According to Ones and Dilchert [36]; "green behavior" can also be defined as scalable actions and behaviors that employees engage in that are related to, and contribute to, or detract from, environmental sustainability [36]. Green behaviour can also result in the acquisition of a sustainable competitive advantage. Employees perceive organizations with green initiatives to be prestigious and therefore engage in supportive behavior [1]. They 
engage in behaviors like saving energy by turning off lights when leaving an office, avoiding waste by electronically correcting documents rather than printing them out, utilizing resources efficiently by using teleconferencing rather than traveling to meetings, and recycling [3,37]. Industrial waste and population growth have serious consequences for humanity and business [38]. However, some research shows that green behavior in the workplace can help the company do better, as shown in Section 2.4.

2.4. Green Behavior and Firm Performance. Previous research has found that green behavior improves company performance $[10,13]$. Employee awareness of environmental sustainability is critical to the company's long-term viability [16]. According to Dumont et al. [10]; an environmentally friendly culture in the workplace will provide employees with motivation and satisfaction, resulting in improved company performance. Therefore, the following hypothesis is proposed for empirical testing:

Hypothesis 2. Green behavior has a significant positive effect on firm performance.

\subsection{Corporate Social Responsibility (CSR) and Green} Behavior. Numerous studies have been conducted to investigate the primary motivations for green behavior in an organization, such as green organizational climates [39], organizational sustainability policies [40], attitudes and beliefs [41], corporate environmental strategy [3], environmental-specific servant leadership [42], demographics factors [43], and green human resource management practices. There is clearly room to delve deeper into the framework's CSR and green behavior to determine how they interact to improve performance and gain a long-term competitive advantage. According to the social information processing theory, an individual's social context and environment influence their attitudes and behaviors [44]. Employees' attitudes and behaviors may be influenced by their evaluation of the work environment, which can be recognized through CSR initiatives, such as hotel employee efforts to benefit the environment or reduce environmental harm, should influence employees' pro-social behaviors (e.g., [35]).

Prior research has found that corporate social responsibility (CSR) is a key determinant of employee proenvironmental behavior (e.g., $[35,45])$. According to the theory of social information processing [46], employees adopt what they perceive to be appropriate workplace behaviors by processing cues from their work environment. Employee perceptions of CSR initiatives influence employee attitudes and behaviors in that workplace, leading to employee engagement in green behavior [35, 39, 42, 45]. Su et al. [47] and Su and Swanson [47] also support a significant link between CSR and green behavior (2019). Furthermore, other research has found that citizenship behaviors (i.e., social and environmental actions) are a result of CSR (e.g., [19, 39, 48]). Therefore, the following hypothesis was proposed:
Hypothesis 3. CSR has a significant positive effect on firms green behaviour.

2.6. Green Behavior as Mediator. According to a mediation model, the independent variable influences the (nonobservable) mediator variable, which influences the dependent variable. As a result, the mediator variable helps us understand how the independent and dependent variables are linked together [49].

Several studies, based on the literature presented above, have revealed a significant relationship between green behavior and firm performance $[10,13]$. The relationship between green behavior and corporate social responsibility $[35,45,48]$. Similarly, there is a link between CSR and firm performance $[25,30,31]$. As a result, green behavior has the potential to serve as a mechanism or process to mediate the relationship between CSR and firm performance, and literature has yet to explain the indirect influence of CSR on firm performance via green behavior. As a result, the purpose of this study is to fill that void. Therefore, the following mediation hypothesis was developed:

Hypothesis 4. Green behavior mediates the relationship between CSR and firm performance

\section{Methods}

The variables used were identified through a review of the literature and taken into consideration during the development of the research structure. It clarifies the findings of an investigation into the combined effects of corporate social responsibility and green behavior on firm performance in the pursuit of sustainable competitive advantage. CSR was identified as an independent variable, green behavior was identified as an independent and mediating variable, and firm performance was identified as the dependent variable.

3.1. Measurement. In this study, a questionnaire was used, and the responses were graded on a five-point Likert scale adapted from Bhatti [50] and Kaliappen, Hilman, and Abubakar [51]; with scores ranging from 1 (strongly disagree) to 5 (strongly agree). The responses were graded as follows: 1 (strongly disagree), 2 (disagree), 3 (neutral), 4 (agree), and 5 (strongly agree). By using a Likert scale, respondents can select a response that best represents their feelings about a given statement or statement of fact. The constructs and items that were used were primarily drawn from previously published literature.

$\mathrm{Su}$ and Swanson [45] identified five dimensions of corporate social responsibility, which are consistent with Dahlsrud [52] and Su et al. [47]. A single question was used to assess each dimension, which was adapted from $\mathrm{Su}$ and Swanson [45] and Dahlsrud [52]. Performance was measured using eight items, four of which were related to financial performance and four of which were related to nonfinancial performance, all of which were adapted from Anwar et al. [53]. Five items adapted from De Roeck and Farooq [35] were used to assess participants' green behavior. 
3.2. Data Collection, Sampling, and Method of Analysis. The total number of direct employees working at the company is 988 , and the industrial unit provides more than 2,000 indirect employment opportunities. $72 \%$ were Nigerian and 28 were foreign experts. Therefore, the population of this study consists of the total of 988 direct staff of Lafarge Africa Plc, Nigerian, with 72\% indigent and 28\% foreign experts. Using the Krejcie and Morgan [54] sample size table, the study took a 278-sample size using the same proportion of foreign and local staff for the fear of representation and better output. Questionnaires were distributed and 172 responded, constituting a $61.8 \%$ response rate.

A smart PLS model was used to evaluate the data obtained, which allowed us to illustrate the link among latent components at the same time while accounting for measurement errors in the structural model. Following the recommendations of Hair et al. [55] and in accordance with the software design, the measurement model was examined independently of the structural model in this study. The rationale for employing Smart PLS has been thoroughly debated in the methodological literature [55]. The simultaneous estimate of various and connected dependent connections between variables, as well as the use of latent construct measurement, are the most frequently noted reasons for utilizing PLS-SEM in management and social sciences research, which was also the reason here. Therefore, the measurement model and the structural model of this study were analyzed and presented in the following section.

\section{Empirical Analyses}

As previously stated in the methodology, the study hypotheses were tested using smart PLS, and the reliability and validity of the study variables were evaluated using the measurement model, which is depicted in Figure 1 and Table 1. Figure 1: Smart PLS was used to test study hypotheses. The path coefficients were determined using the structure model, which is shown in Table 2 and Figure 2, respectively.

4.1. Measurement Model. It has been determined that the reliability of the study constructs is greater than 0.70 on the Cronbach's alpha and composite reliability scales, indicating that the constructs are valid and reliable. According to Fornell and Larcker [56]; all variables has AVE values greater than 0.50 , which is consistent with their recommendations (Table 1). Therefore, the findings are consistent with the convergent validity theory.

4.2. Structure Model. This study tests four hypotheses, as shown in Figure 2 and Table 2. First, the CSR was found to have a significant effect on firm performance with a beta value of 0.458 , t-statistics of 4.282 , and a $P$ value of 0.000 . Secondly, green behavior was also found to have a significant effect on firm performance at a $P$ value of 0.000 , a beta value of 0.423 , and a t-statistics of 4.091. Thirdly, the association between CSR and green behavior was also found to be significant with a beta value of 0.849 , t-statistics of 23.907 , and a $P$ value of 0.001 . Finally, the last hypothesis, which happened to be an indirect link, was also assessed, and it was revealed that green behavior mediates the relationship between CSR and firm performance with values of $=0.359$, $t$-statistics $=4.038$, and a $P$ value of 0.000 . Therefore, the findings support $\mathrm{H} 1, \mathrm{H} 2, \mathrm{H} 3$, and $\mathrm{H} 4$. Table 2 demonstrates information on the direct, indirect, and total effects of the study variables.

The coefficient of determination (R2) is the variance explained in the dependent latent variable by independent latent variables [57]. Therefore, Table 3 shows the calculation of R Square and finds that the firm performance (FP) variable can be explained by other variables in this model by $72 \%$, while green behavior (GB) can be explained in the model by $71.7 \%$. This indicates a good parsimonious model considering having just one independent variable predicting firm performance and one for green behavior.

\section{Discussion of Findings}

This study investigates the connections between CSR, green behavior, and firm performance. According to the findings, CSR can enhance firms' performance if the benefits outweigh the costs. CSR investments can also result in long-term competitive advantages by strengthening a differentiation strategy and by improving a firm's brand and reputation. According to recent research, CSR efforts are more appreciated when the level of competitive activity is high [12]. The findings support the notion that integrating CSR efforts into firms' overall strategies may be more fruitful when combined with prospecting and growth strategies that concentrate on new products and markets.

The findings of this study show that managers can generate value from CSR investments by employing specific business strategies, such as the prospector strategy, which allows for the integration of sustainability strategies into a firm's mainstream strategy. In addition, the second hypothesis examined the impact of green behavior on firm performance, and the results revealed a significant effect. The findings were consistent with previous research that found that green behavior improves company performance $[10,13]$. Employee awareness of environmental sustainability is critical to the company's long-term viability [16]. It is anticipated that this increased awareness will result in a more environmentally friendly workplace. An environmentally friendly work environment is a concept capable of producing a beautiful, comfortable workplace as well as increasing employee motivation and morale, thus ensuring a long-term competitive advantage.

Furthermore, the findings revealed that CSR had a positive impact on employee green behavior. Previous research has found a positive relationship between CSR and green behavior (e.g., [35, 39, 42, 45]. Our findings extend previous research on the link between CSR and green behavior (e.g., [19] by indicating that the combined effect and initiatives that a company performs towards society leads to an improved sustainable competitive advantage. Finally, as shown in the section below, the paper provides firm managers with some implications for an approach that can be 


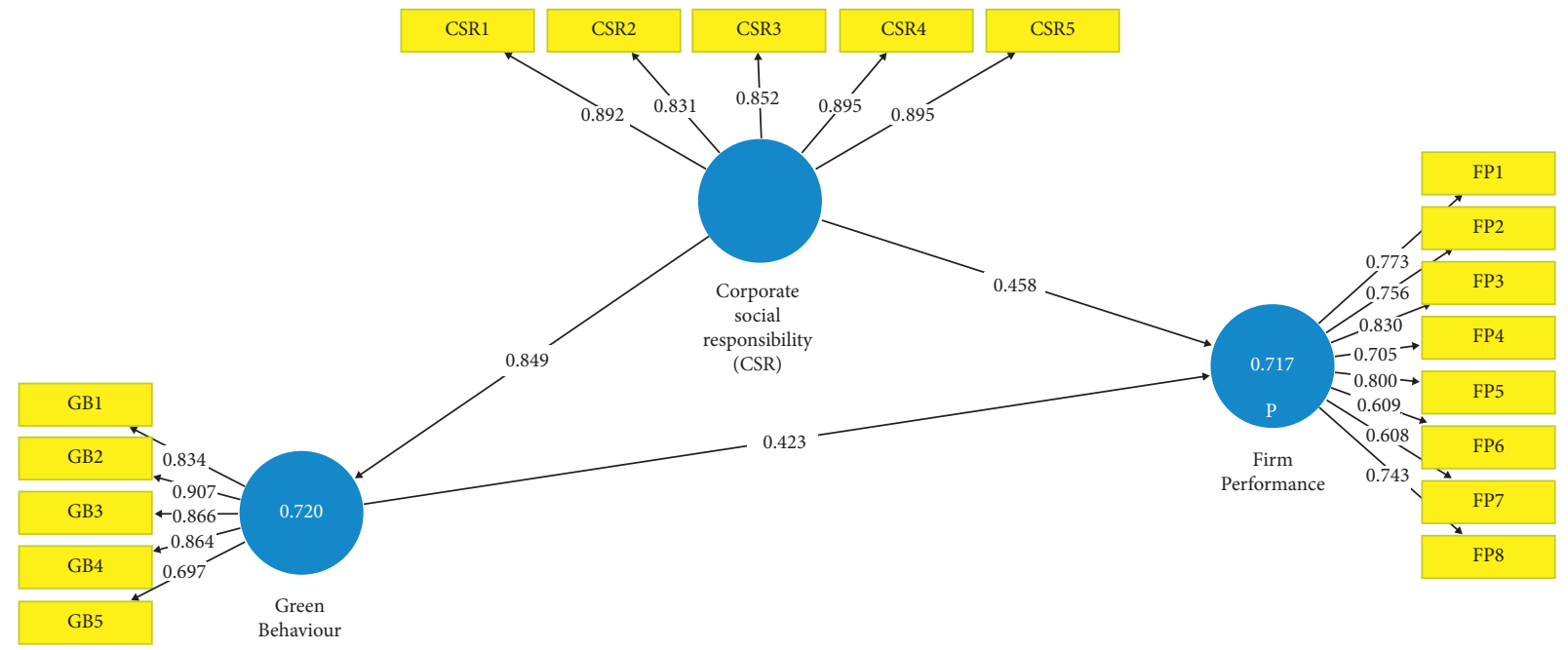

FIGURE 1: SmartPLS algorithm graph.

TABle 1: Construct reliability and validity.

\begin{tabular}{lcccc}
\hline Constructs & Loadings range & Cronbach's $\alpha$ & Composite reliability & Average variance extracted (AVE) \\
\hline Corporate social responsibility (CSR) & $0.831-0.895$ & 0.922 & 0.941 & 0.763 \\
Green behavior (GB) & $0.697-0.907$ & 0.890 & 0.921 & 0.700 \\
Firm performance (FP) & $0.608-0.830$ & 0.873 & 0.901 & 0.536 \\
\hline
\end{tabular}

TABle 2: Mean, STDEV, T values, and $P$ values.

\begin{tabular}{lcccc}
\hline Relationship & $\beta$ & STDEV & T statistics & $P$ value \\
\hline H1: CSR -> FP & 0.458 & 0.107 & 4.282 & 0.000 \\
H2: GB -> FP & 0.423 & 0.103 & 4.091 & 0.000 \\
H3: CSR -> GB & 0.849 & 0.035 & 23.907 & 0.000 \\
H4: CSR -> GB -> FP & 0.359 & 0.089 & 4.038 & 0.000 \\
\hline
\end{tabular}

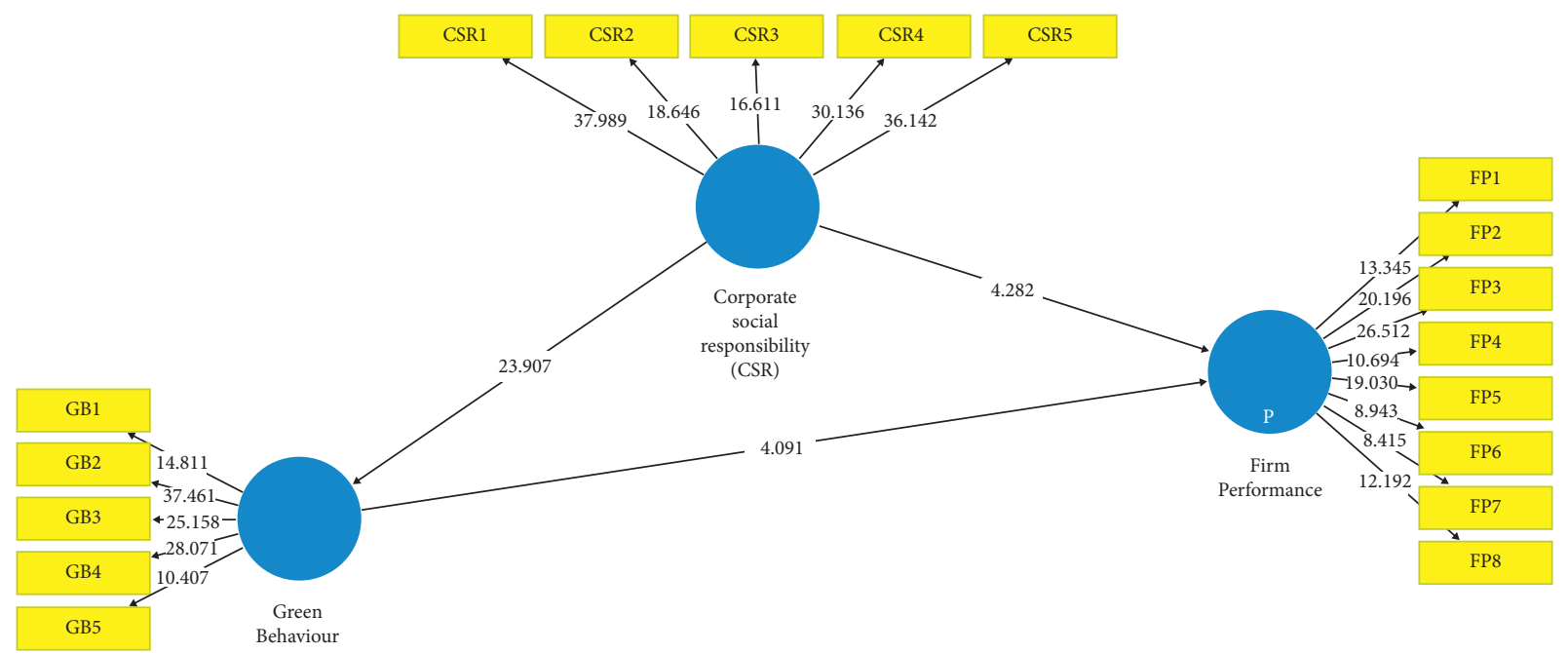

FIGURE 2: SmartPLS bootstrap graph.

TABLE 3: $\mathrm{R}^{2}$ of the dependent variables.

\begin{tabular}{lr}
\hline Constructs & $\mathrm{R}^{2}$ \\
\hline Green behavior (GB) & 0.720 \\
Firm performance (FP) & 0.717 \\
\hline
\end{tabular}


used to motivate employees to engage in green behavior by ensuring that they clearly understand the firm's social responsibility to society.

\section{Conclusions and Implications}

In this study, a model of corporate social responsibility's positive effect on green behavior and firm performance was developed and tested. Green behavior also has an impact on firm performance. CSR has also been shown to have a positive impact on green behavior. Furthermore, through the mediating role of green behavior, CSR has a positive effect on firm performance.

Theoretical Implications: By establishing the mediating role of green behavior, the study contributes to and expands the literature on firm performance and sustainable competitive advantage.

The study expands on previous research on the link between CSR and green behavior by indicating that the combined effect and initiatives that a company performs towards society leads to reputation enhancement and improved sustainable competitive advantage. By adopting green behavior, companies can enhance their performance and attain competitive advantage. Therefore, the managers should therefore strive to create long-term competitive advantages and strengthen the current ones.

Furthermore, based on the findings of the study, corporate social responsibility activities can positively influence employees' participation in green behavior. Top management should recognize the importance of CSR in fostering employee green behavior. The company should communicate clearly with its employees and demonstrate its commitment to environmental and social well-being. Furthermore, the findings revealed that green behavior has a significant mediating influence on the relationship between CSR and firm performance. Thus, green behavior has strengthened the link between CSR and firm performance. This implies that designing CSR activities around the workers' personal environmental norms is an important factor leading to better long-term performance. [58-65].

\section{Limitations}

As for the limitation of the study and future direction, qualitative data collection techniques could be used to understand the relationships between green behavior, CSR, and a firm's performance in a more comprehensive way. In the future, the data can also be collected from indirect employees, as in this study, data was collected explicitly from direct employees.

7.1. Future Research Perspectives. Smart manufacturing makes the deployment of resources easier by reducing the feedback time for decision making and by making the organization more effective [66]. To improve sustainability and competitive advantage in smart manufacturing systems, in order to optimize operational performance and decision making, artificial intelligence could be induced $[67,68]$. The emergence of big data-driven economies has motivated companies to start investing in building artificial intelligence-based decision-making algorithms in order to digitally produce cyber-physical system-based smart factories $[69,70]$. This in turn will affect the reputation of the organization and will positively influence consumers' inclination to buy sustainable products [65]. Therefore, the relationship between sustainable cyber-physical production systems and industrial artificial intelligence with respect to competitive social responsibility could be studied in the future.

Furthermore, what employees perceive to be an environmentally favorable workplace and how they associate with it could also be explored in detail. Additionally, since this is a cross-sectional study, future research should consider a longitudinal approach to compare the outcomes.

\section{Data Availability}

The data that support the findings of this study are primary data collected from direct employees working at the Lafarge Africa Plc company and are available on request from the corresponding author (Abubakar A.,ahmedaphd@ gmail.com).

\section{Conflicts of Interest}

The authors declare that they have no conflicts of interest.

\section{References}

[1] A. Y. C. May, G. S. Hao, and S. Carter, "Intertwining corporate social responsibility, employee green behavior and environmental sustainability: the mediation effect of organizational trust and organizational identity," Economics, Management, and Financial Markets, vol. 16, no. 2, pp. 32-61, 2021.

[2] H. Goworek, C. Land, G. Burt et al., "Scaling sustainability: regulation and resilience in managerial responses to climate change," British Journal of Management, vol. 29, no. 2, pp. 209-219, 2018.

[3] T. A. Norton, H. Zacher, S. L. Parker, and N. M. Ashkanasy, "Bridging the gap between green behavioral intentions and employee green behavior: the role of green psychological climate," Journal of Organizational Behavior, vol. 38, no. 7, pp. 996-1015, 2017.

[4] F. J. Robles-Moral, "Learning about sustainability and SDG with future primary education teachers in initial training," Social Sciences, vol. 10, no. 11, p. 409, 2021.

[5] K. L. Unsworth, M. C. Davis, S. V. Russell, and C. Bretter, "Employee green behavior: HOW organizations can Help the environment," Current Opinion in Psychology, vol. 42, pp. 1-6, 2020.

[6] A. Abubakar, "Coronavirus (COVID-19): effect and survival strategy for businesses," Journal of Economics and Business, vol. 3, no. 2, 2020.

[7] P. Davies, M. P. Hernandez, and T. Wyatt, "Economy versus environment: how corporate actors harm both," Critical Criminology, vol. 27, no. 1, pp. 85-99, 2019.

[8] W. R. D. S. Freitas, J. H. Caldeira-Oliveira, A. A. Teixeira, N. O. Stefanelli, and T. B. Teixeira, "Green human resource management and corporate social responsibility," Benchmarking: An International Journal, vol. 27, no. 4, pp. 15511569, 2020. 
[9] P. Paillé, P. Valéau, and D. W. Renwick, "Leveraging green human resource practices to achieve environmental sustainability," Journal of Cleaner Production, vol. 260, Article ID 121137, 2020.

[10] J. Dumont, J. Shen, and X. Deng, "Effects of green HRM practices on employee workplace green behavior: the role of psychological green climate and employee green values," Human Resource Management, vol. 56, no. 4, pp. 613-627, 2017.

[11] j. Peng, k. Yin, n. Hou, y. Zou, and Q. Nie, "How to facilitate employee green behavior: the joint role of green transformational leadership and green human resource management practice," Acta Psychology Sinica, vol. 52, no. 9, p. 1105, 2020.

[12] H. Kim, E. Woo, M. Uysal, and N. Kwon, "The effects of corporate social responsibility (CSR) on employee well-being in the hospitality industry," International Journal of Contemporary Hospitality Management, vol. 30, no. 3, pp. 15841600, 2018.

[13] A. Kim, Y. Kim, and K. Han, "A cross level investigation on the linkage between job satisfaction and voluntary workplace green behavior," Journal of Business Ethics, vol. 159, no. 4, pp. 1199-1214, 2019.

[14] W. Cai, C. Yang, B. A. G. Bossink, and J. Fu, "Linking leaders' voluntary workplace green behavior and team green innovation: the mediation role of team green efficacy," Sustainability, vol. 12, no. 8, p. 3404, 2020.

[15] N. Soewarno, B. Tjahjadi, and F. Fithrianti, "Green innovation strategy and green innovation: the roles of green organizational identity and environmental organizational legitimacy," Management Decision, vol. 57, no. 11, 2019.

[16] E. Süßbauer and M. Schäfer, "Corporate strategies for greening the workplace: findings from sustainability-oriented companies in Germany," Journal of Cleaner Production, vol. 226, pp. 564-577, 2019.

[17] A. B. Carroll and F. Hoy, "Integrating corporate social policy into strategic management," Journal of Business Strategy, vol. 4, no. 3, 1984.

[18] H. Jo and M. A. Harjoto, "The causal effect of corporate governance on corporate social responsibility," Journal of Business Ethics, vol. 106, no. 1, pp. 53-72, 2012.

[19] K. Hwang and B. Lee, "Pride, mindfulness, public selfawareness, affective satisfaction, and customer citizenship behaviour among green restaurant customers," International Journal of Hospitality Management, vol. 83, pp. 169-179, 2019.

[20] P. Vishwanathan, H. van Oosterhout, P. P. M. A. R. Heugens, P. Duran, and M. Essen, "Strategic CSR: a concept building meta-analysis," Journal of Management Studies, vol. 57, no. 2, pp. 314-350, 2020.

[21] C. Costa, L. F. Lages, and P. Hortinha, "The bright and dark side of CSR in export markets: its impact on innovation and performance," International Business Review, vol. 24, no. 5, pp. 749-757, 2015.

[22] A. McWilliams and D. S. Siegel, "Creating and capturing value," Journal of Management, vol. 37, no. 5, pp. 1480-1495, 2011.

[23] L. Cabral, Living up to Expectations: Corporate Reputation and Sustainable Competitive Advantage, 2012.

[24] J. B. McGuire, A. Sundgren, and T. Schneeweis, "Corporate social responsibility and firm financial performance," Academy of Management Journal, vol. 31, no. 4, pp. 854-872, 1988.

[25] H. Servaes and A. Tamayo, "The impact of corporate social responsibility on firm value: the role of customer awareness," Management Science, vol. 59, no. 5, pp. 1045-1061, 2013.
[26] B. Cheng, I. Ioannou, and G. Serafeim, "Corporate social responsibility and access to finance," Strategic Management Journal, vol. 35, no. 1, pp. 1-23, 2014.

[27] B. Cornell and A. C. Shapiro, Corporate stakeholders and corporate finance, pp. 5-14, Financial management, 1987.

[28] M. E. Porter and M. R. Kramer, "Strategy and society: the link between corporate social responsibility and competitive advantage," Harvard Business Review, vol. 84, no. 12, pp. 78-92, 2006.

[29] I.-A. Hengst, P. Jarzabkowski, M. Hoegl, and M. Muethel, "Toward a process theory of making sustainability strategies legitimate in action," Academy of Management Journal, vol. 63, no. 1, pp. 246-271, 2020.

[30] M. E. Porter and M. R. Kramer, "Creating shared value," Harvard Business Review, vol. 89, no. 1/2, pp. 62-77, 2011.

[31] M. Khan, G. Serafeim, and A. Yoon, "Corporate sustainability: first evidence on materiality," The Accounting Review, vol. 91, no. 6, pp. 1697-1724, 2016.

[32] O. Fawehinmi, M. Y. Yusliza, Z. Mohamad, J. Noor Faezah, and Z. Muhammad, "Assessing the green behaviour of academics," International Journal of Manpower, vol. 41, no. 7, pp. 879-900, 2020.

[33] E. I. Uwem, O. O. Oyedele, and O. T. Olubiyi, "Workplace green behavior for sustainable competitive advantage," $\mathrm{Hu}$ man Resource Management Practices for Promoting Sustainability, pp. 248-263, 2021.

[34] L. Steg and C. Vlek, "Encouraging pro-environmental behaviour: an integrative review and research agenda," Journal of Environmental Psychology, vol. 29, no. 3, pp. 309-317, 2009.

[35] K. De Roeck and O. Farooq, "Corporate social responsibility and ethical leadership: investigating their interactive effect on employees' socially responsible behaviors," Journal of Business Ethics, vol. 151, no. 4, pp. 923-939, 2018.

[36] D. S. Ones and S. Dilchert, "Employee green behaviors," Managing human resources for environmental sustainability, vol. 32, pp. 85-116, 2012.

[37] A. Opoku-Dakwa, C. C. Chen, and D. E. Rupp, "CSR initiative characteristics and employee engagement: an impact-based perspective," Journal of Organizational Behavior, vol. 39, no. 5, pp. 580-593, 2018.

[38] Q. Iqbal, S. H. Hassan, S. Akhtar, and S. Khan, "Employee's green behavior for environmental sustainability: a case of banking sector in Pakistan," World Journal of Science, Technology and Sustainable Development, vol. 15, no. 2, pp. 118130, 2018.

[39] P. Zientara and A. Zamojska, "Green organizational climates and employee pro-environmental behaviour in the hotel industry," Journal of Sustainable Tourism, vol. 26, no. 7, pp. 1142-1159, 2018.

[40] T. A. Norton, H. Zacher, and N. M. Ashkanasy, "Organisational sustainability policies and employee green behaviour: the mediating role of work climate perceptions," Journal of Environmental Psychology, vol. 38, pp. 49-54, 2014.

[41] D. Manika, D. Gregory-Smith, V. K. Wells, L. Comerford, and L. Aldrich-Smith, "Linking environmental sustainability and healthcare: the effects of an energy saving intervention in two hospitals," International Journal of Business Science and Applied Management, vol. 11, no. 1, pp. 32-55, 2017.

[42] T. T. Luu, "Integrating green strategy and green human resource practices to trigger individual and organizational green performance: the role of environmentally-specific servant leadership," Journal of Sustainable Tourism, vol. 28, no. 8, pp. 1193-1222, 2020. 
[43] B. Chekima, S. A. W. Syed Khalid Wafa, O. A. Igau, S. Chekima, and S. L. Sondoh, "Examining green consumerism motivational drivers: does premium price and demographics matter to green purchasing?" Journal of Cleaner Production, vol. 112, pp. 3436-3450, 2016.

[44] J. G. Thomas and R. W. Griffin, "The power of social information in the workplace," Organizational Dynamics, vol. 18 , no. 2, pp. 63-75, 1989.

[45] L. Su and S. R. Swanson, "Perceived corporate social responsibility's impact on the well-being and supportive green behaviors of hotel employees: the mediating role of the employee-corporate relationship," Tourism Management, vol. 72, pp. 437-450, 2019.

[46] G. R. Salancik and J. Pfeffer, "A social information processing approach to job attitudes and task design," Administrative Science Quarterly, vol. 23, no. 2, pp. 224-253, 1978.

[47] B. Su and B. W. Ang, "Multiplicative structural decomposition analysis of aggregate embodied energy and emission intensities," Energy Economics, vol. 65, pp. 137-147, 2017.

[48] H. Han and S. S. Hyun, "Green indoor and outdoor environment as nature-based solution and its role in increasing customer/employee mental health, well-being, and loyalty," Business Strategy and the Environment, vol. 28, no. 4, pp. 629-641, 2019.

[49] D. P. MacKinnon, Introduction to Statistical Mediation Analysis, Routledge, 2012

[50] K. K. Bhatti and T. M. Qureshi, "Impact of employee participation on job satisfaction, employee commitment and employee productivity," International review of business research papers, vol. 3, no. 2, pp. 54-68, 2007.

[51] N. Kaliappen, H. Hilman, and A. Abubakar, "Market orientation and performance: the mediating effect of service quality and moderating effect of star rating system," Journal of Business and Retail Management Research, vol. 11, no. 3, pp. 165-178, 2017.

[52] A. Dahlsrud, "How corporate social responsibility is defined: an analysis of 37 definitions," Corporate Social Responsibility and Environmental Management, vol. 15, no. 1, pp. 1-13, 2008, https://doi.org/10.1002/csr.132.

[53] M. Anwar, A. U. Rehman, and S. Z. A. Shah, "Networking and new venture's performance: mediating role of competitive advantage," International Journal of Emerging Markets, vol. 13, no. 5, 2018.

[54] R. V. Krejcie, "Determining sample size for resource activities in chua lee chuau,(2006) sample size estimation using Krejcie and morgan and cohen statistical power analysis: a comparison," Journal Penyelidikan IPBL, 1970.

[55] D. Harrington, M. Walsh, E. Owens et al., Capitalizing on SME green Innovation Capabilities: Lessons from Irish-Welsh Collaborative Innovation Learning NetworkUniversity Partnerships for International Development. Emerald Group Publishing Limited, 2016.

[56] C. Fornell and D. F. Larcker, Structural Equation Models with Unobservable Variables and Measurement Error: Algebra and Statistics, 1981.

[57] J. Henseler, C. M. Ringle, and R. R. Sinkovics, "The use of partial least squares path modeling in international marketing," in New Challenges to International MarketingEmerald Group Publishing Limited, 2009.

[58] L. M. B. Cabral, Living up to Expectations: Corporate Reputation and Sustainable Competitive Advantage, November 2012.

[59] R. G. Eccles, I. Ioannou, and G. Serafeim, "The impact of corporate sustainability on organizational processes and performance," Management Science, vol. 60, no. 11, pp. 2835-2857, 2014.

[60] I. Ioannou and O. Hawn, "Redefining the strategy field in the age of sustainability," Oxford Handbook of Corporate Social Responsibility: Psychological and Organizational Perspectives, Oxford University Press, 2016.

[61] R. E. Miles, C. C. Snow, A. D. Meyer, and H. J. Coleman Jr, "Organizational strategy, structure, and process," Academy of Management Review, vol. 3, no. 3, pp. 546-562, 1978.

[62] M. Pothitou, R. F. Hanna, and K. J. Chalvatzis, "Environmental knowledge, pro-environmental behaviour and energy savings in households: an empirical study," Applied Energy, vol. 184, pp. 1217-1229, 2016.

[63] M. Sarstedt, C. M. Ringle, and J. F. Hair, "Partial least squares structural equation modeling," Handbook of market research, vol. 26, no. 1, pp. 1-40, 2017.

[64] Q. Uyun, "The effect of green HRM on business sustainability with the mediation role of pro-environmental behavior," Calitatea, vol. 22, no. 183, pp. 163-170, 2021.

[65] E. M. Vătămănescu, D. C. Dabija, P. Gazzola, J. G. CegarraNavarro, and T. Buzzi, "Before and after the outbreak of COVID-19: linking fashion companies' corporate social responsibility approach to consumers' demand for sustainable products," Journal of Cleaner Production, vol. 321, Article ID 128945, 2021.

[66] G. Lăzăroiu, T. Kliestik, and A. Novak, "Internet of things smart devices, industrial artificial intelligence, and real-time sensor networks in sustainable CyberPhysical production systems," Journal of Self-Governance and Management Economics, vol. 9, no. 1, pp. 20-30, 2021.

[67] M. Kovacova and G. Lăzăroiu, "Sustainable industrial big data, automated production processes, and cyber-physical system-based manufacturing in smart networked factories," Economics, Management, and Financial Markets, vol. 16, no. 3, pp. 41-54, 2021.

[68] G. H. Popescu, S. Petreanu, B. Alexandru, and H. Corpodean, "Internet of things-based real-time production logistics, cyber-physical process monitoring systems, and industrial artificial intelligence in sustainable smart manufacturing," Journal of Self-Governance and Management Economics, vol. 9, no. 2, pp. 52-62, 2021.

[69] E. Nica and V. Stehel, "Internet of things sensing networks, artificial intelligence-based decision-making algorithms, and real-time process monitoring in sustainable industry 4.0," Journal of Self-Governance and Management Economics, vol. 9, no. 3, pp. 35-47, 2021.

[70] E. Nica, C. I. Stan, A. G. Luţan, and R. Ş. Oaşa, "Internet of things-based real-time production logistics, sustainable industrial value creation, and artificial intelligence-driven big data analytics in cyber-physical smart manufacturing systems," Economics, Management, and Financial Markets, vol. 16, no. 1, pp. 52-62, 2021. 